OPEN ACCESS

Edited by:

Luigi Janiri,

Catholic University of the Sacred

Heart, Italy

Reviewed by:

Chiara Montemitro,

G. d'Annunzio University of Chieti

and Pescara, Italy

Oussama Kebir,

Institut National de la Santé et de la Recherche Médicale (INSERM),

France

${ }^{*}$ Correspondence: Johan Kakko johan.kakko@regionvasterbotten.se

Specialty section: This article was submitted to

Addictive Disorders,

a section of the journal

Frontiers in Psychiatry

Received: 17 April 2019

Accepted: 26 July 2019

Published: 30 August 2019

Citation:

Kakko J, Alho H, Baldacchino A, Molina R, Nava FA and Shaya $G$

(2019) Craving in Opioid Use

Disorder: From Neurobiology to

Clinical Practice.

Front. Psychiatry 10:592.

doi: 10.3389/fpsyt.2019.00592

\section{Craving in Opioid Use Disorder: From Neurobiology to Clinical Practice}

\author{
Johan Kakko ${ }^{1 *}$, Hannu Alho², Alexander Baldacchino ${ }^{3}$, Rocío Molina $^{4}$, \\ Felice Alfonso $\mathrm{Nava}^{5}$ and Gabriel Shaya ${ }^{6}$
}

${ }^{1}$ Department of Clinical Sciences, Psychiatry, Umeå University, Umeå, Sweden, ${ }^{2}$ Department of Public Health Solutions, The Alcohol, Drugs and Addictions Unit, National Institute of Health and Welfare, Helsinki, Finland, ${ }^{3}$ Division of Population and Behavioural Science, School of Medicine, University of St Andrews, St Andrews, United Kingdom, ${ }^{4}$ Centro de Atencion a las Adicciones de Arganzuela, Madrid Salud, Ayuntamiento de Madrid, Madrid, Spain, ${ }^{5}$ Director Penitentiary Medicine and Drug Abuse Unit, Health Care Unit Padua, Padua, Italy, ${ }^{6}$ Medical Affairs, Indivior UK Ltd, Slough, United Kingdom

Opioid use disorder (OUD) is a major public health issue that has reached epidemic levels in some parts of the world. It is a chronic and complex neurobiological disease associated with frequent relapse to drug taking. Craving, defined as an overwhelmingly strong desire or need to use a drug, is a central component of OUD and other substance use disorders. In this review, we describe the neurobiological and neuroendocrine pathways that underpin craving in OUD and also focus on the importance of assessing and treating craving in clinical practice. Craving is strongly associated with patients returning to opioid misuse and is therefore an important treatment target to reduce the risk of relapse and improve patients' quality of life. Opioid agonist therapies (OAT), such as buprenorphine and methadone, can significantly reduce craving and relapse risk, and it is essential that patients are treated optimally with these therapies. There is also evidence to support the benefits of non-pharmacological approaches, such as cognitive behavioral therapy and mindfulness-based interventions, as supplementary treatments to opioid agonist therapies. However, despite the positive impact of these treatments on craving, many OUD patients continue to suffer with negative affect and dysphoria. There is a clear need for further studies to progress our understanding of the neurobiological basis of craving and addiction and to identify novel therapeutic strategies as well as to optimize the use of existing treatments to improve outcomes for the growing numbers of patients affected by OUD.

Keywords: opioid, craving, addiction, negative affect, methadone, buprenorphine

\section{INTRODUCTION}

Opioid use disorder (OUD) is a major public health burden worldwide and is associated with substantial mortality and morbidity $(1,2)$. A key component of OUD is the development of longlasting drug craving (3-5), whether in the context of prescribed opioids, such as for analgesic purposes, or illicitly acquired heroin. Although a universally agreed definition of drug craving is lacking, in the literature, it has been defined as an intrusive and overwhelming strong desire or compulsion to use a drug because of the memory of the pleasant rewarding effects superimposed on a negative emotional state (6-8). Craving is considered to be central to the motivational drive in addiction (9) and is recognized as an integral component of dependence syndromes, as acknowledged by its incorporation within the latest Diagnostic and Statistical Manual of Mental Disorders 5 
classification system for substance use disorders (10). Craving is also included within the definition of opioid dependence in the recently updated 11th Revision of the International Classification of Diseases system (11).

Craving is a common symptom across substance use disorders beyond opioids, including those relating to alcohol, nicotine, cannabis, cocaine, and other psychoactive substances (11). Although there have been several articles in recent years reviewing data in drug craving $(9,12)$, a focused review of opioid-specific evidence is lacking. In this review, we will discuss the neurobiological foundations for craving, approaches to assessing craving, the importance of craving for predicting the risk of relapse in clinical practice, and the potential for therapies to target craving in OUD.

To identify relevant references, a narrative literature search was conducted in April 2019. The PubMed database was searched using terms related to opioids and craving. Only articles in English were included. Additional references were identified through searching the bibliographies of retrieved articles.

\section{NEUROBIOLOGY OF ADDICTION AND CRAVING IN OPIOID USE DISORDER}

Addiction is a chronic relapsing disease with a neurological basis $(13,14)$. It is therefore important to explore the neurobiological underpinnings of craving in order to better understand the disease process and to identify potential targets of anti-craving medications and non-pharmacological interventions (15). A range of theories describing various aspects of neuroadaptation in addiction have been proposed, including opponent, inhibitory control, reward deficiency, incentive sensitization, aberrant learning, and anti-reward theory (16). The opponent theory, for example, proposes that the euphoria induced by a drug is opposed by a counteracting process that eventually masks the initial hedonic effects (17). In addition, the incentive sensitization theory has been proposed as being particularly relevant for craving. This theory suggests that repeated use of illicit drugs induces neuroadaptations leading to enduring sensitization of dopamine systems with subsequent hyperreactivity in response to drug cues and a pathological degree of incentive salience, manifesting as a disproportionate motivation to pursue the drug $(16,18,19)$. Such an increase in salience associated with drug-related cues is coupled with a reduced sensitivity to normal, non-drug-related rewards (20). A detailed explanation of the various theories of addiction is beyond the scope of the present review and can be found elsewhere (16).

Although early models of addiction focused on hedonic reward, there is now evidence that negative reinforcement may have a particularly important role in maintaining addictive behaviors (21). In this review, we focus our discussion on the neurobiology of addiction based on the cycle of addiction developed by Koob and colleagues (22) (Figure 1).

The cycle of addiction has been proposed to involve three key drivers that underlie the neurobiological changes associated with opioid dependence: i) drug-liking (due to drug intoxication), of which the positive emotions, such as euphoria, are positively reinforcing and increase the probability of using the drug in the early stage of addiction; ii) withdrawal and negative affect, which is associated with negative reinforcement because of the desire to consume a drug in order to improve the affective state and to offset the withdrawal symptoms; and, iii) craving, which relates to the intrusive preoccupation of wanting to use a drug, which can also be associated with

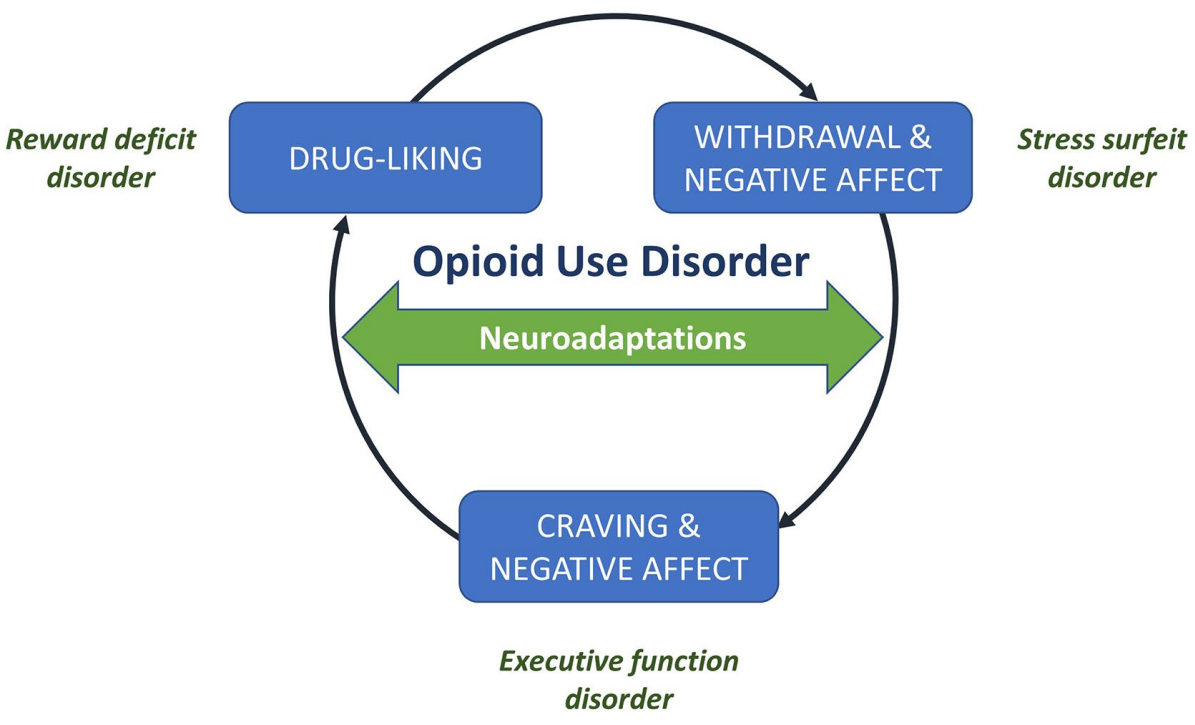

FIGURE 1 | Drivers in the cycle of addiction. The addiction cycle involves three key drivers: (1) pleasurable drug-liking (associated with euphoria in the early stages of addiction), (2) withdrawal and negative affect (the stress and dysphoria associated with withdrawal from a drug), and (3) craving for the drug and ongoing negative affect. Underlying these key drivers are neuroadaptations associated with reward deficit, stress surfeit, and executive function disorders, respectively. Figure reproduced and adapted under the CC-BY license from the ACH Servier Research Group (22). 


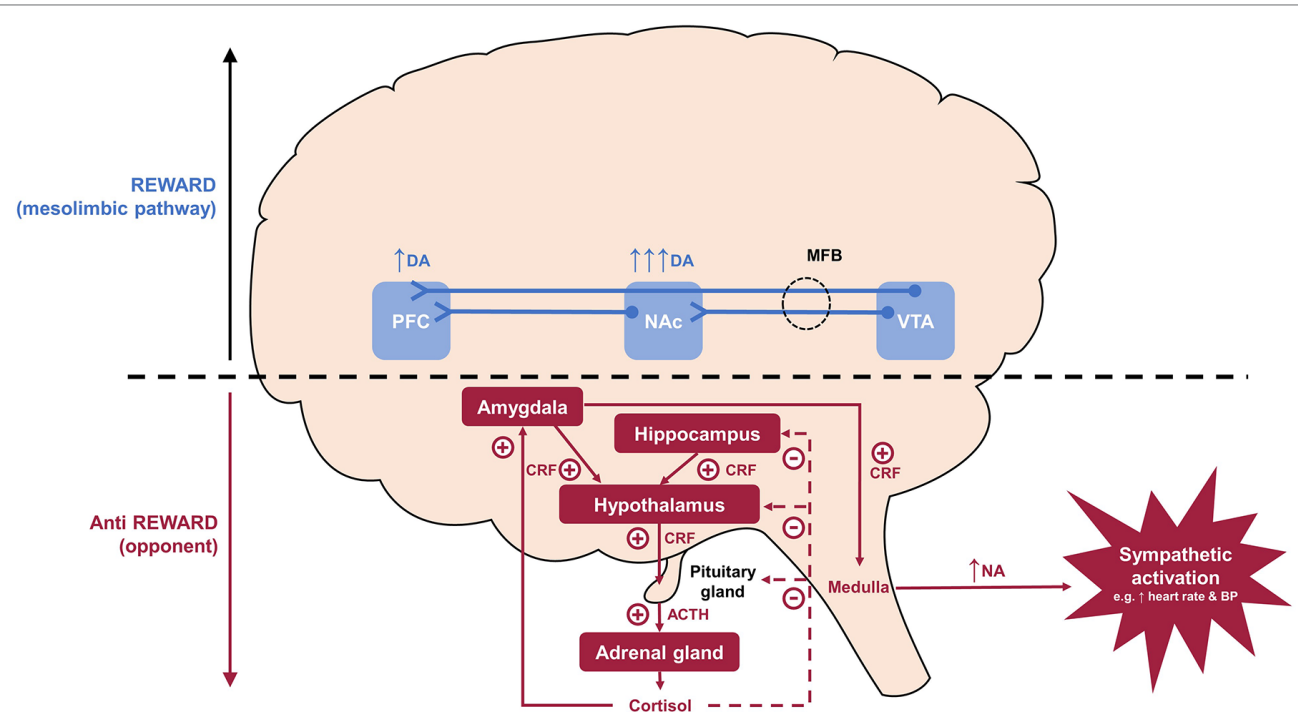

FIGURE 2 | Interface between addiction and stress: Reward versus anti-reward. During acute drug use, the reward system becomes overactive and dopamine is upregulated, especially in the NAc, giving rise to positive reinforcing symptoms, such as drug-liking and euphoria. In the dependent state, the reward system becomes down-regulated and the anti-reward system becomes upregulated and CRF released from the hypothalamic neurons acts on the pituitary to release $\mathrm{ACTH}$, which in turn results in the secretion of cortisol by the adrenal glands. The production of CRF is initially controlled by negative feedback of cortisol on the hippocampus and hypothalamus. However, this is eventually overcome by the production of extra-hypothalamic CRF from the amygdala in a feed-forward manner, which maintains the sympathetic nervous system stress response. This latter pathway produces a stress surfeit that contributes to the negative emotions associated with withdrawal and which goes unbuffered because of the hypodopaminergic tone in the mesolimbic pathway. ACTH, adrenocorticotropic hormone; BP, blood pressure; CRF, corticotropin-releasing factor; DA, dopamine; MFB, medial forebrain bundle; NA, noradrenaline; NAc, nucleus accumbens; PFC, prefrontal cortex; VTA, ventral tegmental area.

negative affect $(23,24)$. All psychoactive drugs target the reward system in the brain producing the positive feelings and emotions that are associated with addiction or dependence (24). This system is opposed by the anti-reward system, which is responsible for the stress, dysphoria, and craving associated with withdrawal (Figure 2) (14). Addiction occurs when there is a deviation from the homeostatic set-point created by the reward and anti-reward systems in the brain (Figure 3) (25).

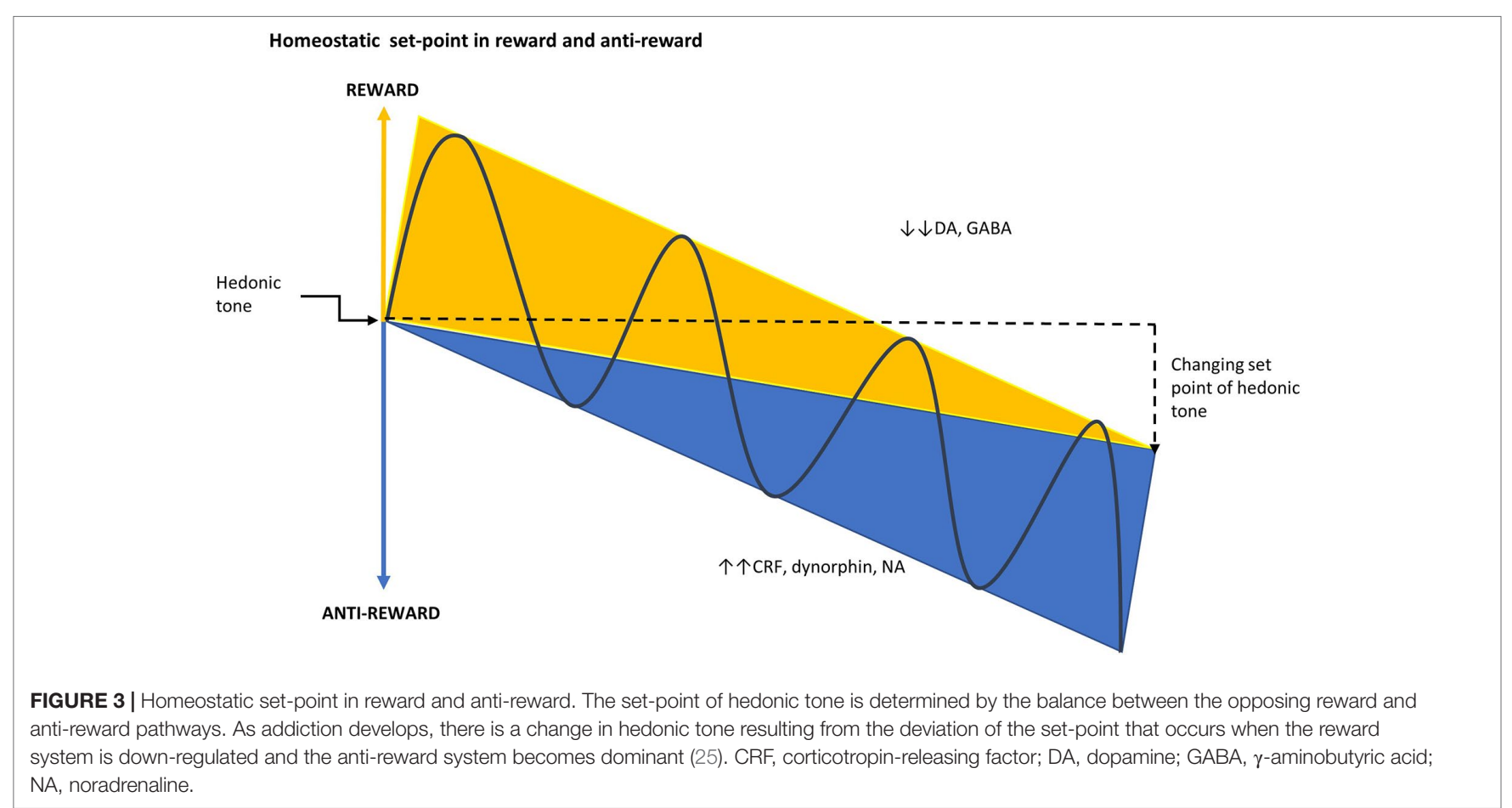


During acute intoxication, the mesolimbic pathway, comprising dopaminergic projections from the ventral tegmental area to the nucleus accumbens (NAc) and frontal cortex, becomes active and dopamine is upregulated, especially in the NAc. This gives rise to positive reinforcing symptoms, such as euphoria (hence the term reward pathway) $(14,24,26)$. Other neurotransmitter systems implicated in positive reinforcement include endogenous opioids, $\gamma$-aminobutyric acid, glutamate, neuropeptide $\mathrm{Y}$, and glucocorticoids (14). The frontal cortex function is relatively preserved in the early stages of addiction and is important in the subjective effects of craving, attribution of salience (assignment of relative value), and inhibitory behavioral control (24).

As addiction progresses, the anti-reward system is recruited through the extended amygdala [a macrostructure consisting of the NAc, amygdala, hypothalamus, and bed nucleus of the stria terminalis (27)] and activates stress pathways mediated by increases in dynorphins, corticotrophin-releasing factor (CRF), and noradrenaline (27). Dynorphins are opioid peptides that are widely distributed in the central nervous system and are increasingly recognized as key mediators of negative emotional states (27). In addiction, dynorphins are believed to play an important role in dysphoria, anhedonia, and compulsive drugseeking behavior $(27,28)$. In response to acute intoxication, excess activation of dopamine receptors in the NAc can upregulate the production of dynorphins, which through kappa $(\kappa)$-opioid receptors (KOR), can exert negative feedback on dopamine release in the mesolimbic system and glutamate release in the NAc (27). This can lead to the mesolimbic system becoming hypodopaminergic and down-regulated, giving rise to anhedonia and tolerance to the euphoric effects of opioids (29).

The anti-reward system is also mediated by the release of CRF from the hypothalamus, which subsequently leads to the secretion of cortisol by the adrenal glands $(27,30)$. In the antireward system, the production of CRF is initially controlled by negative feedback at the level of the hypothalamus and pituitary; however, this brake may eventually be overcome by the production of extra-hypothalamic CRF from the amygdala, driven in a feed-forward manner by the secretion of cortisol. This drives the noradrenergic stress response (at the level of the brainstem) independently of the hypothalamic-pituitaryadrenal (HPA) axis. The release of dynorphins may also be under the control of CRF and conversely CRF release and/or function itself may be controlled by dynorphin-KOR signaling (31-33). A potential link between dynorphins and stress is also supported by the observation that KOR agonists have also been shown to increase cortisol levels in humans and monkeys (34, 35). Ultimately, this dominance of the anti-reward pathway may explain the negative emotions, such as malaise and dysphoria, experienced during withdrawal [reviewed in $(14,24)]$.

In OUD, the importance of the anti-reward system during the withdrawal state is supported by the evidence that cortisol levels are suppressed in patients with active opioid use (3638 ), and then elevated in response to opioid withdrawal upon cessation (39-42). HPA axis dysregulation may persist well beyond the initial acute withdrawal phase, with one study demonstrating that salivary cortisol levels were significantly higher in OUD patients compared with controls for at least 25 days after detoxification (42). Furthermore, heroin craving has been shown to be positively correlated with serum cortisol levels [and negatively correlated with plasma $\beta$-endorphin levels (43)], emphasizing the need to target the anti-reward system in the long-term management of OUD. Exposure to drug-related cues mediates the symptoms of craving in OUD (44-49) and may be linked with increased cortisol responses (50), consistent with the neuroendocrine underpinnings of craving as described in Figure 2. Cue-induced drug seeking is also underpinned by the processes of conditioned reinforcement [described by Koob and Volkow (51) as a previously neutral stimulus that can reinforce behaviors through its association with a primary reinforcer and thus become a reinforcer in its own right] and incentive salience (defined as motivation for rewards that are derived from both a physiological state and previously learned associations about a reward cue). In this setting, activation of the dopamine system in response to repeated exposure to a reward leads to neuroadaptation, ultimately resulting in phasic dopamine system activation in response to neutral cues related to the reward, but not to the reward itself $(22,51)$.

Opioid agonist therapies (OAT), such as buprenorphine and methadone, have been shown to normalize the HPA axis (52, 53). However, despite the impact of OAT on the HPA axis, many heroin-dependent patients continue to experience negative affect, potentially as a result of signaling via extra-hypothalamic CRF (53). The significance of CRF in drug addiction has been extensively studied in animal models (27). Administration of a CRF receptor antagonist has been found to decrease opioid withdrawalinduced negative emotional states (54) and attenuated heroin selfadministration in animals with extended access to the drug (55). Further to these preclinical findings, there has been growing interest in the therapeutic potential of selective CRF antagonists in addiction disorders and in depression, but to date, clinical trials have been unrewarding due to lack of efficacy or due to safety concerns (56). However, some preliminary evidence that CRF antagonism may reduce craving for heroin, albeit with no significant reduction in drug use, has been reported (57). Given the role of the dynorphinKOR system in addiction, research efforts have also focused on the development of selective KOR antagonists $(58,59)$.

Over the past decade, functional imaging has provided further clarification of the relationship between craving and the neurobiological changes of addiction. For example, Li et al. (60) assessed neural responses among heroin-dependent patients following short-term heroin abstinence using functional brain imaging and found that increases in craving in response to drugrelated cues were associated with activation of the mesolimbic dopamine pathway and the prefrontal cortex. Furthermore, similar functional imaging studies demonstrate involvement of the hippocampus and amygdala in cue-elicited craving (24), suggesting the importance of memories and emotion as substrates in craving.

\section{CLINICAL ASSESSMENT OF CRAVING IN OUD}

Assessment of craving through effective patient-physician communication is crucial to the clinical management of patients 
with OUD. Furthermore, the use of simple assessment tools can provide further information on craving, which may be particularly valuable in the research setting as well as in clinical practice. A key challenge in developing reliable tools is the subjective nature of craving (61). Broadly, measures of craving can be divided into two categories-defined as observational and self-reported (61). Observational tools used previously in research studies rely on proxy measures, such as choosing access to drug over a monetary reward or willingness to work to access drug (61). Such tools avoid self-reporting bias and any communication challenges patients may face in articulating their craving symptoms (61). Such assessments are also less dependent on the conscious experience of craving and instead may capture unconscious craving impulses (61). However, observational methods can be challenging to implement in clinical practice and may reflect more than just craving alone $(61,62)$.

Self-reported craving can be evaluated by tools that are specific to craving or as a single item within a broader assessment tool (summarized in Table 1) $(63,72)$. In their simplest form, craving assessment tools can be single-item scales, which allow the responders to indicate their degree of craving using easy-to-understand Likert ratings or visual analogue scales (VAS) (61). Alternatively, multi-item scales can be used to assess craving (62), for example, the Opioid Craving Scale includes three questions each rated on a $0-10$ VAS. The first question asks "How much do you currently crave opiates?", while the remaining questions relate to cue-induced craving and likelihood of use in a prior drug-using environment (63). Self-reported assessments can be limited by ceiling and floor effects, that is, the scale imposes artificial limitations at either extreme, which may prevent distinguishing true differences in craving between patients (12). Although multi-item scales may offer improved reliability and sensitivity compared with singleitem scales $(12,62)$, they can be cumbersome, time-consuming, and lead to respondent disengagement, demotivation, and increased reactivity $(62,63)$.

In recent years, ecological momentary assessments (EMA) have emerged as a novel approach to assessing craving $(74,75)$. EMA involves patient recording of real-time assessments of craving using mobile technology at regular, random, or eventtriggered (e.g., when the patient experiences craving) timepoints each day (74-77). Thus, EMA has the potential to enhance the understanding of craving, particularly in regard to temporal fluctuations $(74,75)$, and potentially to treatment dosing.

The US Food and Drug Administration (FDA) has issued guidance on patient-reported outcome instruments, such as selfreported craving assessments, specifying that instruments should meet a variety of criteria, including reliability, validity, specificity, and sensitivity (78). Furthermore, additional FDA guidance has emphasized that craving tools should complement other end points and correlate with a sustained clinical response (79).

\section{CRAVING IN CLINICAL PRACTICE}

Some patients receiving maintenancetreatment withbuprenorphine or methadone continue to use illicit opioids, drop out from OAT treatment programs, or experience distressing craving symptoms (80). In addition, patients receiving opioid maintenance treatments frequently misuse other drugs, including alcohol, benzodiazepines, cannabis, and gabapentinoids (81, 82). In the European Quality Audit of Opioid Treatment (EQUATOR) survey of patients receiving OAT, 60\% reported either regular or occasional use of illicit drugs while undergoing maintenance

TABLE 1 | Self-reported craving tools for opioid use disorders.

\begin{tabular}{|c|c|c|c|}
\hline Tool & Number of items & Scale & Development \\
\hline Opioid Craving Scale (63) & 3 items & $\begin{array}{l}0-100 \mathrm{~mm} \text { VAS for each item (total } \\
\text { score calculated by averaging the } \\
\text { scores on the } 3 \text { items) }\end{array}$ & $\begin{array}{l}\text { Modified from the Cocaine Craving } \\
\text { Scale }\end{array}$ \\
\hline $\begin{array}{l}\text { Heroin Craving Questionnaire } \\
(61,64-66)\end{array}$ & $\begin{array}{l}\text { 14- and } 45 \text {-item versions available } \\
\text { (45 item version includes five } 9 \text {-item } \\
\text { subscales) }\end{array}$ & $\begin{array}{l}\text { 7-point Likert scale for each item } \\
\text { (total score calculated from individual } \\
\text { items) }\end{array}$ & $\begin{array}{l}\text { Modified from the Cocaine Craving } \\
\text { Questionnaire }\end{array}$ \\
\hline $\begin{array}{l}\text { Modified Penn Alcohol Craving Scale } \\
\text { (67) }\end{array}$ & 5 items & $\begin{array}{l}\text { 7-point scale (total score calculated } \\
\text { as mean of } 5 \text {-item scores) }\end{array}$ & $\begin{array}{l}\text { Modified from the Penn Alcohol Craving } \\
\text { Scale }\end{array}$ \\
\hline $\begin{array}{l}\text { Desires for Drug Questionnaire } \\
(61,67-69)\end{array}$ & $\begin{array}{l}13 \text { items within } 3 \text { domains (desire and } \\
\text { intention, negative reinforcement, and } \\
\text { control) }\end{array}$ & 7-point Likert scale & $\begin{array}{l}\text { Modified from the Desires for Alcohol } \\
\text { Questionnaire }\end{array}$ \\
\hline $\begin{array}{l}\text { Cue-Elicited Craving } \\
\text { Assessment (adapted for } \\
\text { OUD) }(46,70)\end{array}$ & $\begin{array}{l}1 \text { item, administered after exposure to } \\
\text { visual cues relating to opioid use }\end{array}$ & $0-10$ rating scale & $\begin{array}{l}\text { OUD-focused version of generic cue } \\
\text { reactivity test }\end{array}$ \\
\hline $\begin{array}{l}\text { Stress-Elicited Craving } \\
\text { Assessment (adapted for } \\
\text { OUD) (71) }\end{array}$ & $\begin{array}{l}1 \text { item, administered after exposure to } \\
\text { stress-inducing imagery }\end{array}$ & 0-100 mm VAS scale & $\begin{array}{l}\text { OUD-focused version of generic cue } \\
\text { reactivity test }\end{array}$ \\
\hline $\begin{array}{l}\text { Screener and Opioid Assessments for } \\
\text { Pain Patients revised version }(72,73)\end{array}$ & 24 items ( 1 item is specific to craving) & $\begin{array}{l}\text { 0-4 scale (item scores summed for } \\
\text { total score) }\end{array}$ & Novel \\
\hline $\begin{array}{l}\text { Obsessive-Compulsive } \\
\text { Drug Use Scale }(61,68,69)\end{array}$ & $\begin{array}{l}12 \text { items within } 3 \text { domains (thoughts } \\
\text { and interference, intention to use, and } \\
\text { control of consumption) }\end{array}$ & 5 choices per item & $\begin{array}{l}\text { Modified from the Obsessive- } \\
\text { Compulsive Drinking Scale }\end{array}$ \\
\hline
\end{tabular}

OUD, Opioid use disorder; VAS, Visual analogue scale. 
treatment, and $27 \%$ reported heroin use. Of patients who used illicit drugs in addition to OAT, one in six cited lack of control of cravings as the reason for illicit drug use (80). Furthermore, more serious psychiatric manifestations, such as suicidal ideation, depressed mood, and attempts to suppress distressing or intrusive thoughts, have been positively correlated with levels of selfreported opioid craving $(83,84)$, which is why craving symptoms should be monitored upon initiation of OAT.

Identifying and managing triggers for lapse (defined as a temporary and controlled return to drug use) and relapse (a continuous and without control return to drug use) remains an important part of the clinical management of OUD (85). Much research has focused on identifying predictors of relapse in substance use disorders, and one of the strongest candidates to emerge from these studies is craving (86). Although earlier studies provided inconsistent conclusions on the extent to which craving is associated with relapse (74), this may be due to the difficulty in measuring craving retrospectively using traditional recall methods (74). More recent studies utilizing EMA techniques have provided robust evidence that drug craving correlates with risk of subsequent opioid use both in patients receiving buprenorphine or methadone maintenance treatment and in the post-detoxification setting (74, 87-90). Furthermore, EMA methodology has demonstrated that the intensity of craving can increase linearly prior to drug use (87), and that the strength of opioid craving is positively associated with the severity of dependence and negatively associated with readiness to change drug use (91). Beyond the simple risk of relapse, the presence of drug craving can also be a distressing symptom and be disruptive to the functioning of patients (92).

To identify and manage the causes of craving, it may be useful to distinguish between background (tonic) and cue-induced (phasic) craving. Background craving is a slowly changing overall level of craving that occurs in the absence of external cues and may reflect the negative affect associated with abstinence or drug withdrawal and activation of the anti-reward system (9). In support of this theory, a correlation between negative affect and craving has been observed for many substance use disorders (74), and in OUD patients undergoing opioid withdrawal (93). In a study of patients with prescription-opioid dependence who had undergone medically-assisted withdrawal up to 14 days previously, patients with low levels of positive affect were found to be more vulnerable to craving on days when their positive affect was even lower than average (75).

In addition to background craving, episodes of fast-onset, relatively short duration spikes of craving (phasic craving) can be induced by specific drug cues or stressful life events (9), for which craving intensity correlates with stress severity (94). Of note, drug cue exposure and stress episodes can also have additive effects on drug craving (49). Measurements of the intensity, duration, and frequency of these craving episodes may all provide useful prognostic information regarding the risk of relapse (9). Furthermore, the identification of specific triggers for craving may also be a valuable therapeutic focus in the clinical consultation. EMA may allow greater understanding of both the tonic and phasic components of craving, which are typically challenging to differentiate outside of laboratory settings $(9,12,74)$.
Even among heroin users who have been abstinent for greater than a year, drug-related cues still have the potential to elicit craving responses $(47,48)$, highlighting the enduring nature of craving among patients with a history of drug dependence. The influence of different cues on craving may also be dependent on the type of opioid dependence: in heroin dependence, cuerelated craving was stimulated more intensely by paraphernalia images (e.g., needles), whereas patients with analgesic dependence were more stimulated by pills and pill bottles (46). The relationship between life stressors, craving, and relapse is complex and likely to be subject to significant inter-individual differences. For example, preliminary data suggest that women may experience greater increases in craving in response to stress than men (95).

Compared with drug cues, the relationship between pain and craving is less clear. In patients maintained on OAT, chronic pain was associated with three-fold higher odds of experiencing craving for opioids, although this did not lead to a significant increase in drug use (96). Conversely, in patients using prescription opioids for the treatment of chronic pain, craving was not found to be associated with pain itself, but rather with co-occurring anxiety and depressive symptoms, or with a perception of a magnified threat value of pain (97-99). For these patients, the intensity of craving is correlated with the risk of opioid misuse $(70,98,100)$. Many of these patients may require treatment with OAT in order to improve outcomes (101).

\section{CRAVING AS A THERAPEUTIC TARGET IN OUD}

Inhibition of craving has long been a goal of OUD treatment (5). As early as the 1960s, experiments were being conducted using electric shock-based aversion therapy to suppress craving among patients addicted to synthetic opiates (102). In modern times, several pharmacological therapies, notably buprenorphine and methadone, are now available for the treatment of OUD (103). A comparison of the pharmacological characteristics and treatment regimens for methadone and buprenorphine is presented in Table 2. Methadone is a full $\mu$-opioid receptor agonist, whereas buprenorphine is a highaffinity partial $\mu$-opioid receptor agonist (103). Consequently, buprenorphine is associated with a ceiling effect with respect to the risk of respiratory depression (103). As a result of this high-affinity binding with buprenorphine, the effects from any additional illicit opioid use during maintenance treatment can be blocked (103). Other treatment options, including intravenous diamorphine, oral L-methadone, and slow-release oral morphine, have limited availability in most countries and are not considered in this review article.

Numerous studies have demonstrated that buprenorphine and methadone can reduce craving in OUD patients $(108,109)$, which may explain why relapse rates are higher in patients who undergo detoxification or receive psychosocial interventions alone (105). Methadone was the first pharmacotherapy approved in OUD (7) and a systematic review performed by Fareed et al. (108) in 2011 identified seven studies that provided evidence 
TABLE 2 | Comparison of oral/sublingual buprenorphine and methadone in OUD maintenance treatment.

\begin{tabular}{|c|c|c|}
\hline & Buprenorphine & Methadone \\
\hline Pharmacological targets & $\begin{array}{l}\text { - Partial } \mu \text {-opioid } \\
\text { receptor agonist } \\
(104) \\
\text { - } \delta \text {-opioid receptor } \\
\text { antagonist (104) } \\
\text { - } \text { к-opioid receptor } \\
\text { antagonist (104) } \\
\text { - Opioid-like } \\
\text { receptor-1 agonist } \\
\text { (104) }\end{array}$ & $\begin{array}{l}\text { - Full } \mu \text {-opioid receptor } \\
\text { agonist (105) } \\
\text { - N-methyl-D-aspartate } \\
\text { receptor antagonist } \\
\text { (105) }\end{array}$ \\
\hline Average half-life & - 32 h (106) & - 22 h (106) \\
\hline Duration of induction & - 2-3 days (107) & $\begin{array}{l}\text { - 2-4 weeks ("start low, } \\
\text { go slow") (7) }\end{array}$ \\
\hline $\begin{array}{l}\text { Typical induction } \\
\text { regimen }\end{array}$ & $\begin{array}{l}\text { - 2-8 mg on Day } 1 \text { (7) } \\
\text { - Each dose } \\
\text { increased by } \\
2-4 \text { mg up to } \\
24 \text { mg daily (7) }\end{array}$ & $\begin{array}{l}\text { - } \leq 30 \mathrm{mg} / \text { day }(7) \\
\text { - } \text { Increases of } \\
\text { 5-10 mg over } 5 \text { or } \\
\text { more days (7) }\end{array}$ \\
\hline $\begin{array}{l}\text { Typical maintenance } \\
\text { dose }\end{array}$ & $\begin{array}{l}\text { - Maximum } 24^{*} \mathrm{mg} \\
\text { daily (107) }\end{array}$ & • 60-120 mg daily (7) \\
\hline Overdose risk & $\begin{array}{l}\text { - Low risk of } \\
\text { overdose because } \\
\text { of partial agonist } \\
\text { effect and } \\
\text { ceiling effect } \\
\text { for respiratory } \\
\text { depression (7) }\end{array}$ & $\begin{array}{l}\text { - Higher risk from } \\
\text { overdose, particularly } \\
\text { during induction (7) }\end{array}$ \\
\hline
\end{tabular}

*Higher maximum doses exist for some countries. Please consult local prescribing information. OUD, opioid use disorder.

supporting a role for methadone in reducing craving for heroin. This included a study by Shi et al. (110), which demonstrated that long-term methadone maintenance both improved mood and reduced cue-induced craving. A clear illustration of the impact of OAT on craving emerged from a randomized controlled trial comparing buprenorphine/naloxone formulation with placebo over 4 weeks in patients with opiate dependence. In this study, where craving was measured on a $0-100 \mathrm{~mm}$ VAS, mean craving more than halved, with a baseline score of 62.4 reducing to 29.8 after 4 weeks of treatment with a sublingual tablet formulation of $16 \mathrm{mg}$ buprenorphine $/ 4 \mathrm{mg}$ naloxone ( $\mathrm{p}<0.0001$, Figure 4$)$ [(111) and unpublished data].

For both buprenorphine and methadone, the impact on craving is dose dependent $(112,113)$, and it is clear that in order to adequately suppress craving, buprenorphine and methadone must be carefully up-titrated to achieve the optimal dose for each patient (7). The relationship between buprenorphine dose and craving suppression is believed to be determined by the level of availability of $\mu$-opioid receptors (114), and this has been explored in OUD patients using self-reported craving questionnaires and positron emission tomography with a $\mu$-opioid receptor radioligand to explore receptor occupancy. In a preliminary study, Zubieta et al. (115) found that increasing buprenorphine dose aup to $16 \mathrm{mg}$ given as a sublingual liquid [higher bioavailability compared to a sublingual tablet (116)]\} was associated with a significantly greater suppression of craving scores and a 79-95\% reduction in $\mu$-opioid receptor

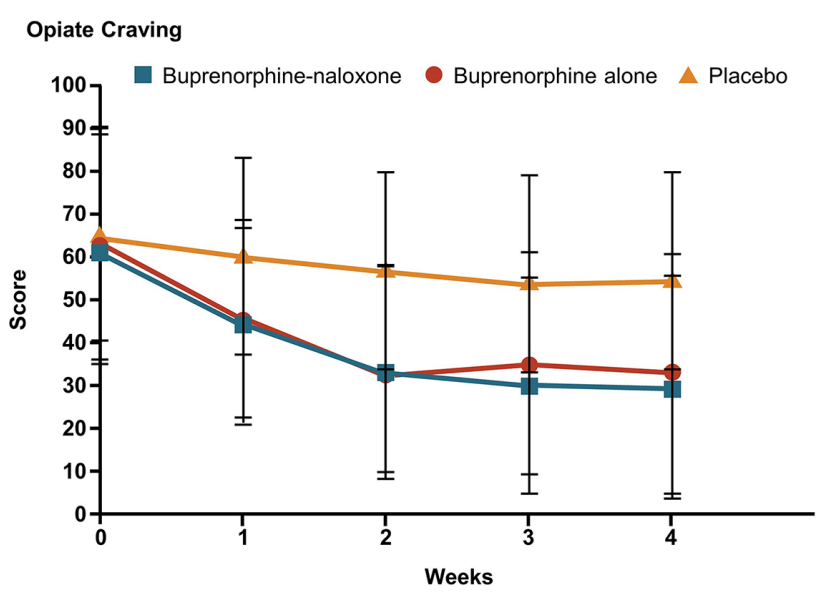

FIGURE 4 | Impact of buprenorphine on self-reported opiate craving among OUD patients (111). Patients were randomized to doubleblind treatment with sublingual tablets consisting of buprenorphine (16 mg), buprenorphine-naloxone (16 mg/4 mg), or placebo given daily for 4 weeks. Self-reported opiate craving was assessed as the peak craving during the prior 24 hours measured on a 0-100 $\mathrm{mm}$ visual analogue scale, with higher scores representing greater craving. Statistically significant reductions in craving $(p<0.001)$ were reported for comparisons between buprenorphine and buprenorphine-naloxone groups versus placebo at all post-baseline time points. OUD, opioid use disorder. Reproduced with permission from the Massachusetts Medical Society.

availability with the $16 \mathrm{mg}$ dose compared with placebo. This was corroborated by Greenwald et al. (117) who found that higher buprenorphine doses (up to $32 \mathrm{mg}$ given as a tablet ${ }^{*}$ ) led to increased plasma buprenorphine levels, decreased $\mu$-opioid receptor availability, and decreased withdrawal symptoms. In the same study, heroin craving was found to be significantly correlated with $\mu$-opioid receptor availability and negatively correlated with buprenorphine plasma levels. These results were expanded in a further study exploring the chronology of $\mu$-opioid receptor availability after buprenorphine dosing in heroin-dependent volunteers. In this study, craving intensity increased significantly from 4 to 76 hours post-dosing, correlating with increasing $\mu$-opioid receptor availability from $30 \%$ to $82 \%$ over this time period among patients who had received buprenorphine (118).

In addition to its ability to reduce symptoms of withdrawal and craving in OUD, buprenorphine may also have a therapeutic impact on dysphoria (119), potentially leading to improvements in treatment retention and quality of life. The impact of buprenorphine on mood may relate to the antagonism it exhibits at $\kappa$-opioid receptors, as there is growing evidence that signaling through these receptors plays a role in the dysphoria and increased sensitivity to stress associated with the anti-reward pathway (120).

Substance use disorders can also be treated with the opioid antagonist naltrexone (121). However, in the context of OUD, naltrexone treatment may increase negative affect and craving through activation of the HPA axis by removal of tonic inhibition by endogenous opioids (122). Consistent with this, studies 
in OUD have demonstrated poor patient adherence to oral naltrexone and failed to show any therapeutic impact of this drug on craving $(105,109,123,124)$.

\section{NON-PHARMACOLOGICAL INTERVENTIONS}

In substance use disorders, patients may benefit from a range of non-pharmacological interventions, such as cognitive behavioral therapy (CBT), motivational interventions, and contingency management (125). Motivational interventions/interviews typically involve brief sessions in which a counselor supports the patients in becoming motivated to change their drug use behavior $(125,126)$. Contingency management approaches provide direct rewards (e.g., vouchers, prizes, or special privileges) to the patients in response to a desired behavior (e.g., drug abstinence) (127).

CBT has been shown to be effective as an integral part of treatment programs that aim to help prevent relapses (125). However, whether CBT has a direct benefit on craving is unclear, as results from studies to date have been inconsistent $(128,129)$. In a study by Ling et al. (128), no significant differences in craving were observed between patients treated with buprenorphine and standard medical management (limited counseling) or buprenorphine combined with either CBT (weekly counseling sessions, exercises, and homework) or contingency management. In contrast, more promising results were obtained from a study of patients receiving methadone maintenance therapy and combined CBT and contingency management. In this study, significantly decreased craving over the course of a 12-week period was reported, although it was limited by the lack of a control arm (129).

Mindfulness, broadly defined as a "systemic development of attention to present moment experience with an attitude of acceptance and non-judging" (130) has been linked with reduced craving in substance use disorders, albeit current evidence has limitations and displays heterogeneity between studies (130-133). In a few studies in patients receiving opioid treatment for chronic pain, mindfulness has been significantly inversely correlated with opioid craving (134136). Mindfulness-based relapse prevention (MBRP) is a novel approach to relapse prevention (a cognitive behavioral group therapy) (137). MBRP has been shown to reduce substance use compared with treatment as usual in patients with substance use disorders in both outpatient and residential settings (137-139). MBRP may prepare patients for environmental relapse risks they encounter after completing residential treatment programs.

Although the extent to which mindfulness can influence the underlying neurobiological changes in addiction is unclear, preliminary evidence in both addiction and non-addiction settings suggests that mindfulness approaches can influence the HPA axis (140-144) and lead to structural changes, including a reduction in gray matter density in the amygdala and an increase in gray matter concentration within the hippocampus $(145,146)$.

\section{EXPERT OPINION}

Craving is a core facet of OUD that has been shown to be associated with the risk of aberrant drug use and relapse in numerous studies. It is underpinned by neurobiological and neuroendocrine adaptations that lead to the dominance of an anti-reward pathway and a change in the set-point of hedonic tone. In daily clinical practice, craving is often still not adequately assessed; however, identifying craving triggers and evaluating the intensity and frequency of craving episodes can be an important part of the management of patients with OUD. Furthermore, craving should be considered as an important treatment target to reduce the risk of relapse and to improve patients' quality of life. When used at optimal doses, pharmacological therapies, such as buprenorphine and methadone, can significantly reduce craving and reduce the risk of relapse. Moreover, evidence to support the benefits of nonpharmacological treatments, such as mindfulness-based therapies, as a supplementary treatment to OAT is beginning to emerge. Despite the positive impact of these treatments, some patients remain at risk of craving and, as a result, relapse to opioids. Patients may also continue to be burdened by the residual negative affect and dysphoria that result from the neurobiological adaptations associated with addiction. These patients frequently misuse other substances, such as central nervous system depressants like alcohol and cannabis, in an effort to self-medicate for the negative affect associated with the overactive amygdala. It is hoped that future studies will further our understanding of the neurobiological basis of craving and drive the development of novel therapeutic strategies along with optimized use of existing treatments in order to improve outcomes for the growing numbers of patients affected by OUD.

*Note: $32 \mathrm{mg}$ dose of buprenorphine is not licensed in all countries (see local prescribing information for details).

\section{AUTHOR CONTRIBUTIONS}

All authors contributed to the first draft of the manuscript, critically revised subsequent drafts, and approved the final version.

\section{FUNDING}

The authors declare that this study received funding from Indivior UK Ltd. Indivior funded medical writing support provided by Stephanie Carter of Spirit Medical Communications in accordance with Good Publication Practice (GPP3) guidelines. One of the authors (GS) is an employee of the funder. The funder was not otherwise involved in the study design, collection, analysis, interpretation of data, the writing of this article or the decision to submit it for publication.

\section{ACKNOWLEDGMENTS}

The authors would like to thank Dr Marc Auriacombe (University of Bordeaux) for his input and advice during the early stages of the development of this manuscript. Medical writing support was provided by Stephanie Carter of Spirit Medical Communications Group Limited and funded by Indivior in accordance with Good Publication Practice (GPP3) guidelines (http://www.ismpp.org/gpp3). 


\section{REFERENCES}

1. GBD 2016 Causes of Death Collaborators. Global, regional, and national age-sex specific mortality for 264 causes of death, 1980-2016: a systematic analysis for the Global Burden of Disease Study 2016. Lancet (2017) 390:1151-210. doi: 10.1016/S0140-6736(17)32152-9

2. United Nations Office on Drugs and Crime (2017). World Drug Report 2017.

3. Kosten TR, George TP. The neurobiology of opioid dependence: implications for treatment. Sci Pract Perspect (2002) 1:13-20. doi: 10.1151/spp021113

4. American Academy of Pain Medicine, the American Pain Society, American Society of Addition Medicine. Definitions related to the use of opioids for the treatment of pain. Wisconsin Med J (2001) 100:28-9.

5. Schuckit MA. Treatment of opioid-use disorders. N Engl J Med (2016) 375:357-68. doi: 10.1056/NEJMra1604339

6. Koob GF, Le Moal M. Addiction and the brain antireward system. Annu Rev Psychol (2008) 59:29-53. doi: 10.1146/annurev.psych.59.103006.093548

7. Dematteis M, Auriacombe M, D’Agnone O, Somaini L, Szerman N, Littlewood R, et al. Recommendations for buprenorphine and methadone therapy in opioid use disorder: a European consensus. Expert Opin Pharmacother (2017) 18:1987-99. doi: 10.1080/14656566.2017.1409722

8. Auriacombe M, Serre F, Denis C, Fatséas M. "Chapter 10. Diagnosis of Addiction". In: Pickard H, Ahmed S, editors. The Routledge Handbook of the Philosophy and Science of Addiction. 1 Edition Routledge (2017).

9. Tiffany ST, Wray JM. The clinical significance of drug craving. Ann N Y Acad Sci (2012) 1248:1-17. doi: 10.1111/j.1749-6632.2011.06298.x

10. Hasin DS, O'Brien CP, Auriacombe M, Borges G, Bucholz K, Budney A, et al. DSM-5 criteria for substance use disorders: recommendations and rationale. Am J Psychiatry (2013) 170:834-51. doi: 10.1176/appi.ajp.2013.12060782

11. ICD-11: International Classification of Diseases 11th Revision: World Health Organization (2018). Available from: https://icd.who.int/browse11.

12. Sayette MA. The role of craving in substance use disorders: theoretical and methodological issues. Annu Rev Clin Psychol (2016) 12:407-33. doi: 10.1146/annurev-clinpsy-021815-093351

13. Savage SR, Joranson DE, Covington EC, Schnoll SH, Heit HA, Gilson AM. Definitions related to the medical use of opioids: evolution towards universal agreement. J Pain Symptom Manage (2003) 26:655-67. doi: 10.1016/ S0885-3924(03)00219-7

14. Koob GF, Le Moal M. Plasticity of reward neurocircuitry and the 'dark side' of drug addiction. Nat Neurosci (2005) 8:1442-4. doi: 10.1038/nn1105-1442

15. Sinha R. The clinical neurobiology of drug craving. Curr Opin Neurobiol (2013) 23:649-54. doi: 10.1016/j.conb.2013.05.001

16. Elman I, Borsook D. Common brain mechanisms of chronic pain and addiction. Neuron (2016) 89:11-36. doi: 10.1016/j.neuron.2015.11.027

17. Koob GF, Le Moal M. Drug addiction, dysregulation of reward, and allostasis. Neuropsychopharmacology (2001) 24:97-129. doi: 10.1016/ S0893-133X(00)00195-0

18. Berridge KC, Robinson TE. Liking, wanting, and the incentivesensitization theory of addiction. Am Psychol (2016) 71:670-9. doi: 10.1037/amp0000059

19. Robinson TE, Berridge KC. Review. The incentive sensitization theory of addiction: some current issues. Philos Trans R Soc Lond B Biol Sci (2008) 363:3137-46. doi: 10.1098/rstb.2008.0093

20. Noel X, Brevers D, Bechara A. A triadic neurocognitive approach to addiction for clinical interventions. Front Psychiatry (2013) 4:179. doi: 10.3389/fpsyt.2013.00179

21. Avery SN, Clauss JA, Blackford JU. The human BNST: functional role in anxiety and addiction. Neuropsychopharmacology (2015) 41:126. doi: $10.1038 /$ npp. 2015.185

22. George O, Koob GF. Individual differences in the neuropsychopathology of addiction. Dialogues Clin Neurosci (2017) 19:217-29.

23. Volkow ND, Koob GF, McLellan AT. Neurobiologic advances from the brain disease model of addiction. N Engl J Med (2016) 374:363-71. doi: 10.1056/NEJMra1511480

24. Koob GF, Volkow ND. Neurocircuitry of addiction. Neuropsychopharmacology (2010) 35:217-38. doi: 10.1038/npp.2009.110

25. Koob GF. Hedonic homeostatic dysregulation as a driver of drug-seeking behavior. Drug Discovery Today Dis Models (2008) 5:207-15. doi: 10.1016/j. ddmod.2009.04.002
26. Adinoff B. Neurobiologic processes in drug reward and addiction. Harv Rev Psychiatry (2004) 12:305-20. doi: 10.1080/10673220490910844

27. Koob GF, Buck CL, Cohen A, Edwards S, Park PE, Schlosburg JE, et al. Addiction as a stress surfeit disorder. Neuropharmacology (2014) $76 \mathrm{Pt}$ B:370-82. doi: 10.1016/j.neuropharm.2013.05.024

28. Butelman ER, Yuferov V, Kreek MJ. Kappa-opioid receptor/dynorphin system: genetic and pharmacotherapeutic implications for addiction. Trends Neurosci (2012) 35:587-96. doi: 10.1016/j.tins.2012.05.005

29. Gold MS, Blum K, Febo M, Baron D, Modestino EJ, Elman I, et al. Molecular role of dopamine in anhedonia linked to reward deficiency syndrome (RDS) and anti-reward systems. Front Biosci (2018) 10:309-25. doi: 10.2741/s518

30. Bruchas MR, Land BB, Chavkin C. The dynorphin/kappa opioid system as a modulator of stress-induced and pro-addictive behaviors. Brain Res (2010) 1314:44-55. doi: 10.1016/j.brainres.2009.08.062

31. Nikolarakis KE, Almeida OF, Herz A. Stimulation of hypothalamic betaendorphin and dynorphin release by corticotropin-releasing factor (in vitro). Brain Res (1986) 399:152-5. doi: 10.1016/0006-8993(86)90610-4

32. Land BB, Bruchas MR, Lemos JC, Xu M, Melief EJ, Chavkin C. The dysphoric component of stress is encoded by activation of the dynorphin kappa-opioid system. J Neurosci (2008) 28:407-14. doi: 10.1523/JNEUROSCI.4458-07.2008

33. Valdez GR, Platt DM, Rowlett JK, Ruedi-Bettschen D, Spealman RD. Kappa agonist-induced reinstatement of cocaine seeking in squirrel monkeys: a role for opioid and stress-related mechanisms. J Pharmacol Exp Ther (2007) 323:525-33. doi: 10.1124/jpet.107.125484

34. Ur E, Wright DM, Bouloux PM, Grossman A. The effects of spiradoline (U-62066E), a kappa-opioid receptor agonist, on neuroendocrine function in man. Br J Pharmacol (1997) 120:781-4. doi: 10.1038/sj.bjp.0700971

35. Pascoe JE, Williams KL, Mukhopadhyay P, Rice KC, Woods JH, Ko M-C. Effects of mu, kappa, and delta opioid receptor agonists on the function of hypothalamic-pituitary-adrenal axis in monkeys. Psychoneuroendocrinology (2008) 33:478-86. doi: 10.1016/j.psyneuen.2008.01.006

36. Eisenman AJ, Fraser HF, Brooks JW. Urinary excretion and plasma levels of 17-hydroxycorticosteroids during a cycle of addiction to morphine. $J$ Pharmacol Exp Ther (1961) 132:226-31.

37. Eisenman AJ, Fraser HF, Sloan J, Isbell H. Urinary 17-ketosteroid excretion during a cycle of addiction to morphine. J Pharmacol Exp Ther (1958) 124:305-11.

38. Facchinetti F, Volpe A, Farci G, Petraglia F, Porro CA, Barbieri G, et al. Hypothalamus-pituitary-adrenal axis of heroin addicts. Drug Alcohol Depend (1985) 15:361-6. doi: 10.1016/0376-8716(85)90014-6

39. Kreek MJ, Koob GF. Drug dependence: stress and dysregulation of brain reward pathways. Drug Alcohol Depend (1998) 51:23-47. doi: 10.1016/ S0376-8716(98)00064-7

40. Li SX, Li J, Epstein DH, Zhang XY, Kosten TR, Lu L. Serum cortisol secretion during heroin abstinence is elevated only nocturnally. Am J Drug Alcohol Abuse (2008) 34:321-8. doi: 10.1080/00952990802013664

41. Cami J, Gilabert M, San L, de la Torre R. Hypercortisolism after opioid discontinuation in rapid detoxification of heroin addicts. Br J Addict (1992) 87:1145-51. doi: 10.1111/j.1360-0443.1992.tb02001.x

42. Bearn J, Buntwal N, Papadopoulos A, Checkley S. Salivary cortisol during opiate dependence and withdrawal. Addict Biol (2001) 6:157-62. doi: 10.1080/13556210020040235

43. Shi J, Li SX, Zhang XL, Wang X, Le Foll B, Zhang XY, et al. Time-dependent neuroendocrine alterations and drug craving during the first month of abstinence in heroin addicts. Am J Drug Alcohol Abuse (2009) 35:267-72. doi: 10.1080/00952990902933878

44. Behera D, Goswami U, Khastgir U, Kumar S. Craving by imagery cue reactivity in opiate dependence following detoxification. Indian J Psychiatry (2003) 45:178-81.

45. Back SE, Gros DF, McCauley JL, Flanagan JC, Cox E, Barth KS, et al. Laboratory-induced cue reactivity among individuals with prescription opioid dependence. Addict Behav (2014) 39:1217-23. doi: 10.1016/j. addbeh.2014.04.007

46. McHugh RK, Fulciniti F, Mashhoon Y, Weiss RD. Cue-induced craving to paraphernalia and drug images in opioid dependence. Am J Addict (2016) 25:105-9. doi: 10.1111/ajad.12344

47. Wang GB, Zhang XL, Zhao LY, Sun LL, Wu P, Lu L, et al. Drug-related cues exacerbate decision making and increase craving in heroin addicts at 
different abstinence times. Psychopharmacol (Berl) (2012) 221:701-8. doi: 10.1007/s00213-011-2617-5

48. Zhao M, Fan C, Du J, Jiang H, Chen H, Sun H. Cue-induced craving and physiological reactions in recently and long-abstinent heroin-dependent patients. Addict Behav (2012) 37:393-8. doi: 10.1016/j.addbeh.2011.11.030

49. Preston KL, Kowalczyk WJ, Phillips KA, Jobes ML, Vahabzadeh M, Lin JL, et al. Exacerbated craving in the presence of stress and drug cues in drugdependent patients. Neuropsychopharmacology (2018) 43:859-67. doi: 10.1038/npp.2017.275

50. Fatseas $M$, Denis $C$, Massida $Z$, Verger M, Franques-Reneric P, Auriacombe M. Cue-induced reactivity, cortisol response and substance use outcome in treated heroin dependent individuals. Biol Psychiatry (2011) 70:720-7. doi: 10.1016/j.biopsych.2011.05.015

51. Koob GF, Volkow ND. Neurobiology of addiction: a neurocircuitry analysis. Lancet Psychiatry (2016) 3:760-73. doi: 10.1016/S2215-0366(16)00104-8

52. Kreek MJ, Ragunath J, Plevy S, Hamer D, Schneider B, Hartman N. ACTH, Cortisol and beta-endorphin response to metyrapone testing during chronic methadone maintenance treatment in humans. Neuropeptides (1984) 5:277- 278. doi: 10.1016/0143-4179(84)90081-7

53. Kakko J, von Wachenfeldt J, Svanborg KD, Lidstrom J, Barr CS, Heilig M. Mood and neuroendocrine response to a chemical stressor, metyrapone, in buprenorphine-maintained heroin dependence. Biol Psychiatry (2008) 63:172-7. doi: 10.1016/j.biopsych.2007.05.001

54. Stinus L, Cador M, Zorrilla EP, Koob GF. Buprenorphine and a CRF1 antagonist block the acquisition of opiate withdrawal-induced conditioned place aversion in rats. Neuropsychopharmacology (2005) 30:90-8. doi: 10.1038/sj.npp.1300487

55. Greenwell TN, Funk CK, Cottone P, Richardson HN, Chen SA, Rice KC, et al. Corticotropin-releasing factor-1 receptor antagonists decrease heroin self-administration in long- but not short-access rats. Addict Biol (2009) 14:130-43. doi: $10.1111 / j .1369-1600.2008 .00142 . x$

56. Spierling SR, Zorrilla EP. Don't stress about CRF: assessing the translational failures of CRF1antagonists. Psychopharmacol (Berl) (2017) 234:1467-81. doi: 10.1007/s00213-017-4556-2

57. Morabbi MJ, Razaghi E, Moazen-Zadeh E, Safi-Aghdam H, Zarrindast MR, Vousoghi N, et al. Pexacerfont as a CRF1 antagonist for the treatment of withdrawal symptoms in men with heroin/methamphetamine dependence: a randomized, double-blind, placebo-controlled clinical trial. Int Clin Psychopharmacol (2018) 33:111-9. doi: 10.1097/ YIC. 0000000000000200

58. Helal MA, Habib ES, Chittiboyina AG. Selective kappa opioid antagonists for treatment of addiction, are we there yet? Eur J Med Chem (2017) 141:632-47. doi: 10.1016/j.ejmech.2017.10.012

59. Carlezon WA, Jr., Krystal AD. Kappa-opioid antagonists for psychiatric disorders: from bench to clinical trials. Depress Anxiety (2016) 33:895- 906. doi: 10.1002/da.22500

60. Li Q, Wang Y, Zhang Y, Li W, Yang W, Zhu J, et al. Craving correlates with mesolimbic responses to heroin-related cues in short-term abstinence from heroin: an event-related fMRI study. Brain Res (2012) 1469:63-72. doi: $10.1016 /$ j.brainres.2012.06.024

61. Rosenberg H. Clinical and laboratory assessment of the subjective experience of drug craving. Clin Psychol Rev (2009) 29:519-34. doi: 10.1016/j.cpr.2009.06.002

62. Sayette MA, Shiffman S, Tiffany ST, Niaura RS, Martin CS, Shadel WG. The measurement of drug craving. Addiction (2000) 95 Suppl 2:S189- 210. doi: 10.1046/j.1360-0443.95.8s2.8.x

63. McHugh RK, Fitzmaurice GM, Carroll KM, Griffin ML, Hill KP, Wasan $\mathrm{AD}$, et al. Assessing craving and its relationship to subsequent prescription opioid use among treatment-seeking prescription opioid dependent patients. Drug Alcohol Depend (2014) 145:121-6. doi: 10.1016/j.drugalcdep.2014.10.002

64. Tiffany ST, Fields L, Singleton E, Haertzen C, Henningsfield JE. The development of a heroin craving questionnaire. Unpublished manuscript, Perdue University, 1993.

65. Heinz AJ, Epstein DH, Schroeder JR, Singleton EG, Heishman SJ, Preston KL. Heroin and cocaine craving and use during treatment: measurement validation and potential relationships. J Subst Abuse Treat (2006) 31:355-64. doi: 10.1016/j.jsat.2006.05.009
66. Greenwald MK. Heroin craving and drug use in opioid-maintained volunteers: effects of methadone dose variations. Exp Clin Psychopharmacol (2002) 10:39-46. doi: 10.1037//1064-1297.10.1.39

67. Tsui JI, Anderson BJ, Strong DR, Stein MD. Craving predicts opioid use in opioid-dependent patients initiating buprenorphine treatment: a longitudinal study. Am J Drug Alcohol Abuse (2014) 40:163-9. doi: 10.3109/00952990.2013.848875

68. Hassani-Abharian P, Mokri A, Ganjgahi H, Oghabian MA, Ekhtiari H. Validation for persian versions of "desire for drug questionnaire" and "obsessive compulsive drug use scale" in heroin dependents. Arch Iran Med (2016) 19:659-65. doi: 0161909/AIM.0010

69. Franken IH, Hendriksa VM, van den Brink W. Initial validation of two opiate craving questionnaires the obsessive compulsive drug use scale and the desires for drug questionnaire. Addict Behav (2002) 27:675-85. doi: 10.1016/S0306-4603(01)00201-5

70. Garland EL, Howard MO. Opioid attentional bias and cue-elicited craving predict future risk of prescription opioid misuse among chronic pain patients. Drug Alcohol Depend (2014) 144:283-7. doi: 10.1016/j. drugalcdep.2014.09.014

71. Hyman SM, Fox H, Hong KI, Doebrick C, Sinha R. Stress and drug-cueinduced craving in opioid-dependent individuals in naltrexone treatment. ExpClin Psychopharmacol(2007) 15:134-43. doi: 10.1037/1064-1297.15.2.134

72. Butler SF, Fernandez K, Benoit C, Budman SH, Jamison RN. Validation of the revised Screener and Opioid Assessment for Patients with Pain (SOAPP-R). J Pain (2008) 9:360-72. doi: 10.1016/j.jpain.2007.11.014

73. Finkelman MD, Kulich RJ, Zacharoff KL, Smits N, Magnuson BE, Dong J, et al. Shortening the Screener and Opioid Assessment for Patients with PainRevised (SOAPP-R): a proof-of-principle study for customized computerbased testing. Pain Med (2015) 16:2344-56. doi: 10.1111/pme.12864

74. Serre F, Fatseas M, Swendsen J, Auriacombe M. Ecological momentary assessment in the investigation of craving and substance use in daily life: a systematic review. Drug Alcohol Depend (2015) 148:1-20. doi: 10.1016/j. drugalcdep.2014.12.024

75. Huhn AS, Harris J, Cleveland HH, Lydon DM, Stankoski D, Cleveland MJ, et al. Ecological momentary assessment of affect and craving in patients in treatment for prescription opioid dependence. Brain Res Bull (2016) 123:94101. doi: 10.1016/j.brainresbull.2016.01.012

76. Moskowitz DS, Young SN. Ecological momentary assessment: what it is and why it is a method of the future in clinical psychopharmacology. J Psychiatry Neurosci (2006) 31:13-20.

77. Preston KL, Jobes ML, Phillips KA, Epstein DH. Real-time assessment of alcohol drinking and drug use in opioid-dependent polydrug users. Behav Pharmacol (2016) 27:579-84. doi: 10.1097/FBP.0000000000000250

78. U.S. Department of Health and Human Services, Food and Drug Administration, Center for Drug Evaluation and Research (CDER), Center for Biologics Evaluation and Research (CBER), Center for Devices and Radiological Health (CDRH) (2009). Guidance for industry: patientreported outcome measures: use in medical product development to support labeling claims. https://www.fda.gov/downloads/drugs/guidances/ ucm193282.pdf.

79. US Food and Drug Administration. Opioid Use Disorder: Endpoints for Demonstrating Effectiveness of Drugs for Medication-Assisted Treatment Guidance for Industry (2018). U.S. Department of Health and Human Services, Food and Drug Administration, Center for Drug Evaluation and Research (CDER). https://www.fda.gov/downloads/Drugs/ GuidanceComplianceRegulatoryInformation/Guidances/UCM615743.pdf.

80. Fischer G, Nava F, Stover H. Outcomes of opioid-dependence treatment across Europe: identifying opportunities for improvement. Heroin Addict Relat Clin Prob (2012) 14:39-50.

81. Heikman PK, Muhonen LH, Ojanperä IA. Polydrug abuse among opioid maintenance treatment patients is related to inadequate dose of maintenance treatment medicine. BMC psychiatry (2017) 17:245. doi: 10.1186/ s12888-017-1415-y

82. Soyka M. Alcohol use disorders in opioid maintenance therapy: prevalence, clinical correlates and treatment. Eur Addict Res (2015) 21:78-87. doi: $10.1159 / 000363232$

83. Garland EL, Riquino MR, Priddy SE, Bryan CJ. Suicidal ideation is associated with individual differences in prescription opioid craving and 
cue-reactivity among chronic pain patients. J Addict Dis (2017) 36:23-9. doi: 10.1080/10550887.2016.1220800

84. Garland EL, Brown SM, Howard MO. Thought suppression as a mediator of the association between depressed mood and prescription opioid craving among chronic pain patients. J Behav Med (2016) 39:128-38. doi: 10.1007/ s10865-015-9675-9

85. Ducray K, Darker C, Smyth BP. Situational and psycho-social factors associated with relapse following residential detoxification in a population of Irish opioid dependent patients. Ir J Psychol Med (2012) 29:72-9. doi: 10.1017/S079096670001733X

86. Witkiewitz K, Bowen S, Douglas H, Hsu SH. Mindfulness-based relapse prevention for substance craving. Addict Behav (2013) 38:1563-71. doi: 10.1016/j.addbeh.2012.04.001

87. Preston KL, Kowalczyk WJ, Phillips KA, Jobes ML, Vahabzadeh M, Lin JL, et al. Before and after: craving, mood, and background stress in the hours surrounding drug use and stressful events in patients with opioid-use disorder. Psychopharmacol (Berl) (2018) 235:2713-23. doi: 10.1007/ s00213-018-4966-9

88. Johnson EI, Barrault M, Nadeau L, Swendsen J. Feasibility and validity of computerized ambulatory monitoring in drug-dependent women. Drug Alcohol Depend (2009) 99:322-6. doi: 10.1016/j.drugalcdep.2008.06.010

89. Fatseas M, Serre F, Alexandre JM, Debrabant R, Auriacombe M, Swendsen J. Craving and substance use among patients with alcohol, tobacco, cannabis or heroin addiction: a comparison of substance- and person-specific cues. Addiction (2015) 110:1035-42. doi: 10.1111/add.12882

90. Fatseas M, Serre F, Swendsen J, Auriacombe M. Effects of anxiety and mood disorders on craving and substance use among patients with substance use disorder: An ecological momentary assessment study. Drug Alcohol Depend (2018) 187:242-8. doi: 10.1016/j.drugalcdep.2018.03.008

91. Yen CF, Lin HC, Wang PW, Ko CH, Lee KH, Hsu CY, et al. Heroin craving and its correlations with clinical outcome indicators in people with heroin dependence receiving methadone maintenance treatment. Compr Psychiatry (2016) 65:50-6. doi: 10.1016/j.comppsych.2015.10.001

92. Tiffany ST, Friedman L, Greenfield SF, Hasin DS, Jackson R. Beyond drug use: a systematic consideration of other outcomes in evaluations of treatments for substance use disorders. Addict (Abingdon, Engl) (2012) 107:709-18. doi: 10.1111/j.1360-0443.2011.03581.x

93. Swift RM, Stout RL. The relationship between craving, anxiety, and other symptoms in opioid withdrawal. J Subst Abuse (1992) 4:19-26. doi: 10.1016/0899-3289(92)90024-R

94. Preston KL, Kowalczyk WJ, Phillips KA, Jobes ML, Vahabzadeh M, Lin JL, et al. Context and craving during stressful events in the daily lives of drugdependent patients. Psychopharmacol (Berl) (2017) 234:2631-42. doi: 10.1007/ s00213-017-4663-0

95. Moran LM, Kowalczyk WJ, Phillips KA, Vahabzadeh M, Lin JL, Mezghanni M, et al. Sex differences in daily life stress and craving in opioid-dependent patients. AmJ Drug Alcohol Abuse (2018) 44:512-23. doi: 10.1080/00952990.2018.1454934

96. Tsui JI, Lira MC, Cheng DM, Winter MR, Alford DP, Liebschutz JM, et al. Chronic pain, craving, and illicit opioid use among patients receiving opioid agonist therapy. Drug Alcohol Depend (2016) 166:26-31. doi: 10.1016/j. drugalcdep.2016.06.024

97. Martel MO, Finan PH, McHugh RK, Issa M, Edwards RR, Jamison RN, et al. Dayto-day pain symptoms are only weakly associated with opioid craving among patients with chronic pain prescribed opioid therapy. Drug Alcohol Depend (2016) 162:130-6. doi: 10.1016/j.drugalcdep.2016.02.047

98. Martel MO, Dolman AJ, Edwards RR, Jamison RN, Wasan AD. The association between negative affect and prescription opioid misuse in patients with chronic pain: the mediating role of opioid craving. J Pain (2014) 15:90-100. doi: 10.1016/j.jpain.2013.09.014

99. Martel MO, Jamison RN, Wasan AD, Edwards RR. The association between catastrophizing and craving in patients with chronic pain prescribed opioid therapy: a preliminary analysis. Pain Med (2014) 15:1757-64. doi: 10.1111/ pme. 12416

100. Wasan AD, Butler SF, Budman SH, Fernandez K, Weiss RD, Greenfield SF, et al. Does report of craving opioid medication predict aberrant drug behavior among chronic pain patients? Clin J Pain (2009) 25:193-8. doi: 10.1097/ AJP.0b013e318193a6c4
101. Kakko J, Gedeon C, Sandell M, Grelz H, Birkemose I, Clausen T, et al. Principles for managing OUD related to chronic pain in the Nordic countries based on a structured assessment of current practice. Subst Abuse Treat Prev Policy (2018) 13:22. doi: 10.1186/s13011-018-0160-7

102. Wolpe J. Conditioned inhibition of craving in drug addiction: a pilot experiment. Behav Res Ther (1965) 3:285-8. doi: 10.1016/0005-7967(64)90035-X

103. Noble F, Marie N. Management of opioid addiction with opioid substitution treatments: beyond methadone and buprenorphine. Front Psychiatry (2019) 9:742. doi: 10.3389/fpsyt.2018.00742

104. Robinson SE. Buprenorphine: an analgesic with an expanding role in the treatment of opioid addiction. CNS Drug Rev (2002) 8:377-90. doi: 10.1111/ j.1527-3458.2002.tb00235.x

105. Bart G. Maintenance medication for opiate addiction: the foundation of recovery. J Addict Dis (2012) 31:207-25. doi: 10.1080/10550887.2012.694598

106. Saxon AJ, Hser YI, Woody G, Ling W. Medication-assisted treatment for opioid addiction: methadone and buprenorphine. J Food Drug Anal (2013) 21:S69-72. doi: 10.1016/j.jfda.2013.09.037

107. European Medicines Agency (2016). Suboxone summary of product charactersitics. https://www.ema.europa.eu/documents/product-information/ suboxone-epar-product-information_en.pdf.

108. Fareed A, Vayalapalli S, Stout S, Casarella J, Drexler K, Bailey SP. Effect of methadone maintenance treatment on heroin craving, a literature review. J Addict Dis (2011) 30:27-38. doi: 10.1080/10550887.2010.531672

109. Fareed A, Vayalapalli S, Casarella J, Amar R, Drexler K. Heroin anticraving medications: a systematic review. Am J Drug Alcohol Abuse (2010) 36:33241. doi: $10.3109 / 00952990.2010 .505991$

110. Shi J, Zhao LY, Epstein DH, Zhang XL, Lu L. Long-term methadone maintenance reduces protracted symptoms of heroin abstinence and cueinduced craving in Chinese heroin abusers. Pharmacol Biochem Behav (2007) 87:141-5. doi: 10.1016/j.pbb.2007.04.010

111. Fudala PJ, Bridge TP, Herbert S, Williford WO, Chiang CN, Jones K, et al. Office-based treatment of opiate addiction with a sublingual-tablet formulation of buprenorphine and naloxone. N Engl J Med (2003) 349:94958. doi: 10.1056/NEJMoa022164

112. Preston KL, Umbricht A, Epstein DH. Methadone dose increase and abstinence reinforcement for treatment of continued heroin use during methadone maintenance. Arch Gen Psychiatry (2000) 57:395-404. doi: 10.1001/archpsyc.57.4.395

113. Ling W, Charuvastra C, Collins JF, Batki S, Brown LS, Jr., Kintaudi P, et al. Buprenorphine maintenance treatment of opiate dependence: a multicenter, randomized clinical trial. Addiction (1998) 93:475-86. doi: 10.1046/j.1360-0443.1998.9344753.x

114. Greenwald MK, Comer SD, Fiellin DA. Buprenorphine maintenance and mu-opioid receptor availability in the treatment of opioid use disorder: implications for clinical use and policy. Drug Alcohol Depend (2014) 144:111. doi: 10.1016/j.drugalcdep.2014.07.035

115. Zubieta J, Greenwald MK, Lombardi U, Woods JH, Kilbourn MR, Jewett DM, et al. Buprenorphine-induced changes in mu-opioid receptor availability in male heroin-dependent volunteers: a preliminary study. Neuropsychopharmacology (2000) 23:326-34. doi: 10.1016/ S0893-133X(00)00110-X

116. Nath RP, Upton RA, Everhart ET, Cheung P, Shwonek P, Jones RT, et al. Buprenorphine pharmacokinetics: relative bioavailability of sublingual tablet and liquid formulations. J Clin Pharmacol (1999) 39:619-23. doi: $10.1177 / 00912709922008236$

117. Greenwald MK, Johanson CE, Moody DE, Woods JH, Kilbourn MR, Koeppe RA, et al. Effects of buprenorphine maintenance dose on mu-opioid receptor availability, plasma concentrations, and antagonist blockade in heroin-dependent volunteers. Neuropsychopharmacology (2003) 28:2000-9. doi: 10.1038/sj.npp.1300251

118. Greenwald M, Johanson CE, Bueller J, Chang Y, Moody DE, Kilbourn M, et al. Buprenorphine duration of action: mu-opioid receptor availability and pharmacokinetic and behavioral indices. Biol Psychiatry (2007) 61:101-10. doi: 10.1016/j.biopsych.2006.04.043

119. Gerra G, Fantoma A, Zaimovic A. Naltrexone and buprenorphine combination in the treatment of opioid dependence. J Psychopharmacol (2006) 20:806-14. doi: 10.1177/0269881106060835 
120. Volkow ND, Morales M. The brain on drugs: from reward to addiction. Cell (2015) 162:712-25. doi: 10.1016/j.cell.2015.07.046

121. Jahagirdar D, Wright MD. "CADTH Rapid Response Reports". In: Naltrexone for opioid use disorders: a review of clinical effectiveness, cost-effectiveness, and guidelines. Canadian Agency for Drugs and Technologies in Health (2017).

122. Roche DJ, Childs E, Epstein AM, King AC. Acute HPA axis response to naltrexone differs in female vs. male smokers. Psychoneuroendocrinology (2010) 35:596-606. doi: 10.1016/j.psyneuen.2009.09.016

123. Hulse GK, Ngo HT, Tait RJ. Risk factors for craving and relapse in heroin users treated with oral or implant naltrexone. Biol Psychiatry (2010) 68:296- 302. doi: 10.1016/j.biopsych.2010.04.003

124. Krupitsky E, Zvartau E, Blokhina E, Verbitskaya E, Wahlgren V, TsoyPodosenin M, et al. Anhedonia, depression, anxiety, and craving in opiate dependent patients stabilized on oral naltrexone or an extended release naltrexone implant. Am J Drug Alcohol Abuse (2016) 42:614-20. doi: 10.1080/00952990.2016.1197231

125. McHugh RK, Hearon BA, Otto MW. Cognitive behavioral therapy for substance use disorders. Psychiatr Clin North Am (2010) 33:511-25. doi: 10.1016/j.psc.2010.04.012

126. Smedslund G, Berg RC, Hammerstrom KT, Steiro A, Leiknes KA, Dahl HM, et al. Motivational interviewing for substance abuse. Cochrane Database Syst $\operatorname{Rev}$ (2011) (10):CD008063. doi: 10.1002/14651858.CD008063.pub2

127. Ainscough TS, McNeill A, Strang J, Calder R, Brose LS. Contingency Management interventions for non-prescribed drug use during treatment for opiate addiction: A systematic review and meta-analysis. Drug Alcohol Depend (2017) 178:318-39. doi: 10.1016/j.drugalcdep.2017.05.028

128. Ling W, Hillhouse M, Ang A, Jenkins J, Fahey J. Comparison of behavioral treatment conditions in buprenorphine maintenance. Addiction (2013) 108:1788-98. doi: 10.1111/add.12266

129. Willner-Reid J, Whitaker D, Epstein DH, Phillips KA, Pulaski AR, Preston KL, et al. Cognitive-behavioural therapy for heroin and cocaine use: Ecological momentary assessment of homework simplification and compliance. Psychol Psychother (2016) 89:276-93. doi: 10.1111/papt.12080

130. Chiesa A, Serretti A. Are mindfulness-based interventions effective for substance use disorders?A systematic review of the evidence. Subst Use Misuse (2014) 49:492-512. doi: 10.3109/10826084.2013.770027

131. Grant S, Colaiaco B, Motala A, Shanman R, Booth M, Sorbero M, et al. Mindfulness-based relapse prevention for substance use disorders: a systematic review and meta-analysis. J Addict Med (2017) 11:386-96. doi: 10.1097/ADM.0000000000000338

132. Cavicchioli M, Movalli M, Maffei C. The clinical efficacy of mindfulnessbased treatments for alcohol and drugs use disorders: a meta-analytic review of randomized and nonrandomized controlled trials. Eur Addict Res (2018) 24:137-62. doi: 10.1159/000490762

133. Li W, Howard MO, Garland EL, McGovern P, Lazar M. Mindfulness treatment for substance misuse: A systematic review and meta-analysis. J Subst Abuse Treat (2017) 75:62-96. doi: 10.1016/j.jsat.2017.01.008

134. Baker AK, Garland EL. Autonomic and affective mediators of the relationship between mindfulness and opioid craving among chronic pain patients. Exp Clin Psychopharmacol (2019) 27:55-63. doi: 10.1037/pha0000225

135. Priddy SE, Hanley AW, Riquino MR, Platt KA, Baker AK, Garland EL. Dispositional mindfulness and prescription opioid misuse among chronic pain patients: craving and attention to positive information as mediating mechanisms. Drug Alcohol Depend (2018) 188:86-93. doi: 10.1016/j. drugalcdep.2018.03.040
136. Garland EL, Manusov EG, Froeliger B, Kelly A, Williams JM, Howard MO. Mindfulness-oriented recovery enhancement for chronic pain and prescription opioid misuse: results from an early-stage randomized controlled trial. J Consult Clin Psychol (2014) 82:448-59. doi: 10.1037/ a0035798

137. Bowen S, Chawla N, Collins SE, Witkiewitz K, Hsu S, Grow J, et al. Mindfulness-based relapse prevention for substance use disorders: a pilot efficacy trial. Subst Abus (2009) 30:295-305. doi: 10.1080/08897070903250084

138. Bowen S, Witkiewitz K, Clifasefi SL, Grow J, Chawla N, Hsu SH, et al. Relative efficacy of mindfulness-based relapse prevention, standard relapse prevention, and treatment as usual for substance use disorders: a randomized clinical trial. JAMA Psychiatry (2014) 71:547-56. doi: 10.1001/ jamapsychiatry.2013.4546

139. Davis JP, Berry D, Dumas TM, Ritter E, Smith DC, Menard C, et al. Substance use outcomes for mindfulness based relapse prevention are partially mediated by reductions in stress: results from a randomized trial. J Subst Abuse Treat (2018) 91:37-48. doi: 10.1016/j.jsat.2018.05.002

140. Branstrom R, Kvillemo P, Akerstedt T. Effects of mindfulness training on levels of cortisol in cancer patients. Psychosomatics (2013) 54:158-64. doi: 10.1016/j.psym.2012.04.007

141. Carlson LE, Speca M, Patel KD, Goodey E. Mindfulness-based stress reduction in relation to quality of life, mood, symptoms of stress and levels of cortisol, dehydroepiandrosterone sulfate (DHEAS) and melatonin in breast and prostate cancer outpatients. Psychoneuroendocrinology (2004) 29:448-74. doi: 10.1016/S0306-4530(03)00054-4

142. Brand S, Holsboer-Trachsler E, Naranjo JR, Schmidt S. Influence of mindfulness practice on cortisol and sleep in long-term and short-term meditators. Neuropsychobiology (2012) 65:109-18. doi: 10.1159/000330362

143. Sanada K, Montero-Marin J, Alda Díez M, Salas-Valero M, Pérez-Yus MC, Morillo $\mathrm{H}$, et al. Effects of mindfulness-based interventions on salivary cortisol in healthy adults: a meta-analytical review. Front Physiol (2016) 7:471. doi: 10.3389/fphys.2016.00471

144. Marcus MT, Fine M, Moeller FG, Khan MM, Pitts K, Swank PR, et al. Change in stress levels following mindfulness-based stress reduction in a therapeutic community. Addict Disord Treat (2003) 2:63-8. doi: 10.1097/00132576-200302030-00001

145. Holzel BK, Carmody J, Evans KC, Hoge EA, Dusek JA, Morgan L, et al. Stress reduction correlates with structural changes in the amygdala. Soc Cogn Affect Neurosci (2010) 5:11-7. doi: 10.1093/scan/nsp034

146. Holzel BK, Carmody J, Vangel M, Congleton C, Yerramsetti SM, Gard T, et al. Mindfulness practice leads to increases in regional brain gray matter density. Psychiatry Res (2011) 191:36-43. doi: 10.1016/j.pscychresns.2010.08.006.

Conflict of Interest Statement: JK, HA, RM, and FN have received consultancy fees from Indivior UK Ltd. AB has received unrestricted educational grants from Schering Plough, Merck Serono, Lundbeck, and Indivior. GS is an employee of Indivior UK Ltd.

Copyright () 2019 Kakko, Alho, Baldacchino, Molina, Nava and Shaya. This is an open-access article distributed under the terms of the Creative Commons Attribution License (CC BY). The use, distribution or reproduction in other forums is permitted, provided the original author(s) and the copyright owner(s) are credited and that the original publication in this journal is cited, in accordance with accepted academic practice. No use, distribution or reproduction is permitted which does not comply with these terms. 